\title{
Potential Implications of Sea-Level Rise for Belgium
}

\author{
Luc Lebbe ${ }^{\dagger}$, Nathalie Van Meir ${ }^{\dagger}$, and Peter Viaene \\ Ghent University \\ Department of Geology and Soil Science \\ Laboratory of Applied Geology and \\ Hydrogeology \\ Krijgslaan, 281 (S8) \\ B-9000 Gent \\ Belgium \\ luc.lebbe@rug.ac.be \\ *Ministry of the Flemish Community \\ Environment and Infrastructure \\ Department \\ Waterways and Maritime Affairs \\ Administration \\ Hydraulic Laboratory and Hydrological \\ Research Division \\ Berchemlei 115 \\ B-2140 Borgerhout \\ Belgium
}

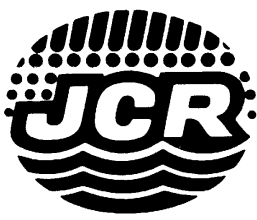

\begin{abstract}
LEBBE, L.; VAN MEIR, N., and VIAENE, P., 2008. Potential implications of sea-level rise for Belgium. Journal of Coastal Research, 24(2), 358-366. West Palm Beach (Florida), ISSN 0749-0208.

The Belgian coastal plain and the Schelde estuary are threatened by sea-level rise. While of great economic importance with a threatened population of some 0.8 million (of a total population of 10 million), assessments of these risks are limited. This article describes the physical characteristics of the coast and undertakes a qualitative interpretation of its vulnerability. Low-lying polders are the most vulnerable to sea-level rise where a major problem is water drainage during rainy periods; their varying vulnerability to sea-level rise and increase in rain intensity is assessed, including the relationship between drainage levels and saltwater seepage. Freshwater lenses developed within the dunes are also vulnerable to sea-level rise, leading to threats to drinking water supplies from saltwater intrusion. Belgian coastal defence structures and their effectiveness are discussed. Historical sea-level rise during the past century, wave and wind data, and the evolution of erosion and accretion along the coast are interpreted. For Antwerpen, a harbour city on the river Schelde, the effects of sea-level rise are far from clear. Included here are historical data on changes in tidal amplitude during the 20th century. Future research needs should focus on the quantitative interpretation of data to understand the effect of sea-level rise on beach erosion, flood risk, and fresh and salt groundwater distribution. Furthermore, a thorough socio-economic study should be undertaken to assess the vulnerability of the Belgian coast and the Schelde estuary.
\end{abstract}

ADDITIONAL INDEX WORDS: Belgian coastal plain, saltwater intrusion, gravitational and artificial water drainage, coastal defences.

\section{PHYSICAL CHARACTERISTICS OF THE BELGIAN COASTAL PLAIN}

\section{Geographical Position and Economic Relevance}

The Belgian coastline is on the southern North Sea and comprises an open wave-exposed coast and the more sheltered upper reaches of the Schelde estuary. The wave-exposed coast (65-km long) has a nearly continuous dune belt that protects the hinterland. This dune barrier consists of two arcs, one stretching from Dunkerque (France) to Wenduine and a second arc from Wenduine to Breskens (The Netherlands). Its continuity is interrupted by the estuaries of the river IJzer in the west and het Zwin in the east and the harbours of Oostende, Blankenberge, and Zeebrugge. The total coastal zone population is ca. 0.4 million (i.e., ca. $4 \%$ of the Belgian population), which is concentrated in the towns of Brugge, Oostende, Blankenberge, Veurne, Nieuwpoort, and Knokke (Figure 1).

During summer holidays the population increases by $c a$. 0.3 million resident tourists and on peak days by 0.25 million

DOI: 10.2112/07A-0009.1 received and accepted in revision 19 April 2007. day trippers. The economic importance of the coast is mainly a consequence of beach tourism and agriculture in the lowlying polder areas with the combined economic activities from tourism, fishing, and harbour activity generating $€ 2.7$ billion per year (ALLAERT, 1996).

Although the Schelde estuary is mainly situated in The Netherlands, its socio-economic importance for Belgium is paramount. The harbour city of Antwerpen (population, 0.4 million) is situated in an area of low-lying polders in the upper reaches of the Schelde estuary (Figure 2). Two Dutch harbours, Vlissingen and Terneuzen, are located along the Schelde estuary, whereas another Belgian harbour, Gent, is connected to the estuary by a sea canal. Therefore, a cooperation exists between The Netherlands and Flanders (the northern part of the Federal State of Belgium) on harbour policy decisions. Of these four harbours, Antwerpen is the most important economically. The yearly added values of harbour activities (1997/1998 average) are $€ 9.1$ billion (Antwerpen), $€ 3.1$ billion (Gent), $€ 2.1$ billion (Vlissingen), and $€ 1.5$ billion (Terneuzen). The harbours of Antwerpen and Gent provide jobs for 153,000 people directly and indirectly, and their socio-economic importance for Belgium is significant. The estuary is also used for sand extraction, fisheries, and nature 


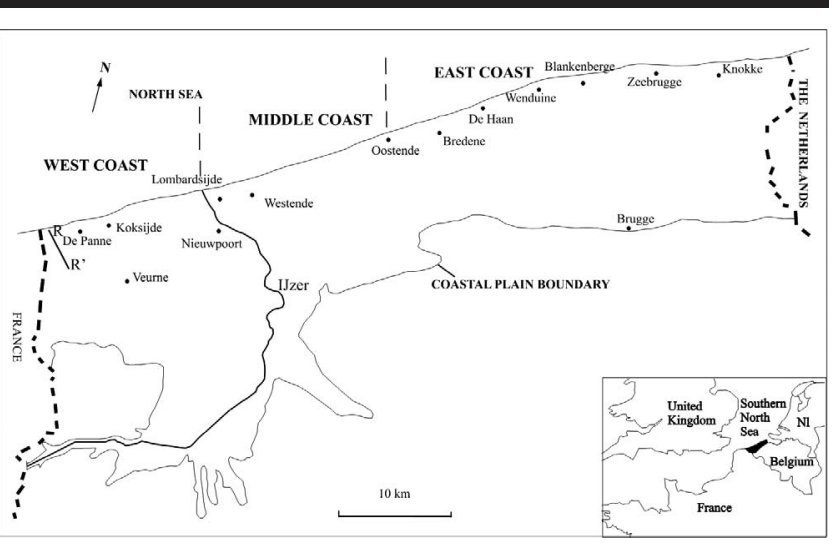

Figure 1. The Belgian coastal plain, its geographical position in the North Sea, the landward limit of $5 \mathrm{~m}$ TAW, indication of dune areas, and the location of the resistivity profile R-R'.

reserves. The morphology of the Schelde estuary has changed significantly due to natural and human actions, which has had repercussions for the functionality of the area. Human action in recent years has consisted of dredging, changes in channel width, and construction of river defences. It is expected that tides and the river bed will have adjusted to the impact of these activities in 10 to 15 years (ZANTING and TEN THIJ, 2001), assuming there is no further interference.

\section{Geology}

The clastic sediments of the coastal plain are of Quaternary age and are underlain by a thick Tertiary clay formation (MVG, 1993; VIAENE, 2000). They form a wedge that is thickest in the east, thins to the west, and also decreases from the coast in the direction of the polders. Most of these sediments were deposited after the last Glacial Stage some 10,000 years $\mathrm{BP}$, mainly after sea-level rise slowed down some 6000 years $\mathrm{BP}$, and are of Atlantic age or younger. Pleistocene sediments are also present, but to a lesser extent (DENYs et al., 1983; Denys and Baeteman, 1995; Mostaert, 1985). The Quaternary sediments consist of sand, coarse sand with shells, clay, and peat layers. The reduction in sea-level rise about 6000 years BP was also responsible for the form of the coastal plain: a natural barrier of dunes, shore, and foreshore with no tidal inlets (a closed coast) protecting a low-lying plain.

\section{Geomorphology and Occupation}

The landward limit of the Belgian coastal plain is defined by the topographical contour of $5 \mathrm{~m} \mathrm{TAW}^{1}$ (Figure 1). Between the dunes and hinterland a landscape characterised by channels and intertidal flats formerly existed, but is now occupied by polders. Despite the presence of a dune barrier, the

${ }^{1}$ The Belgian datum level (TAW, Tweede Algemene Waterpassing, Second General Leveling) corresponds with the low low water at Oostende (1839-1858); $0 \mathrm{~m}$ TAW is $2.33 \mathrm{~m}$ below the zero of NAP (Datum Level of the Netherlands), which corresponds to average mean sea level during the last 300 years.

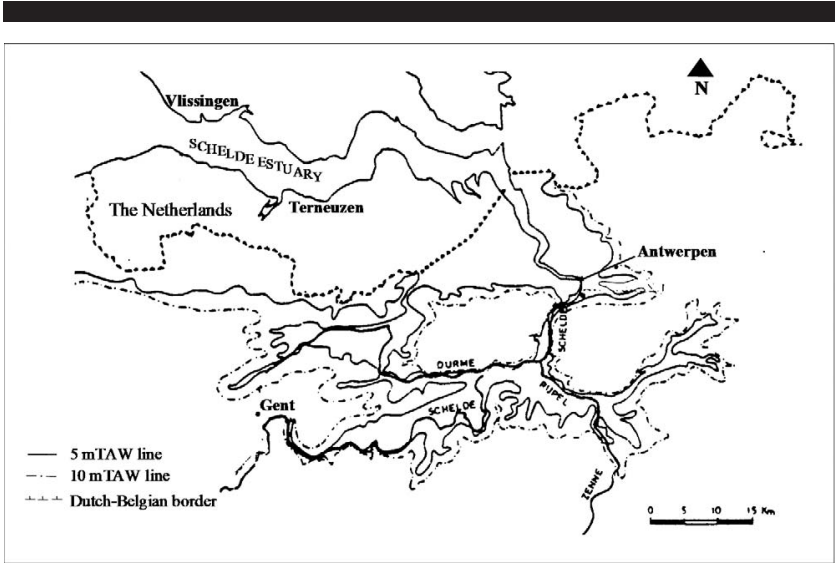

Figure 2. The Schelde estuary and the indication of the harbour cities Antwerpen, Gent, Terneuzen, and Vlissingen (adapted from Baeteman et al., 1992).

sea has entered the hinterland during storms at several breaching points and through tidal channels. From the 11th century onward people inhabiting the coastal plain started protecting their land and houses by building dikes and creating polders. This process has shaped the present coastal plain with sand-filled channels and creeks producing higher land levels than the mudflats consisting of clay and peat, which have experienced settlement and consolidation (MosTAERT, 1986; MVG, 1993). The plain is now subdivided in three parts: the low-lying polder areas, the dunes, and the shore with the low-lying polder areas forming the major part of the coastal plain. The width of the low-lying coastal plain ranges between $10 \mathrm{~km}$ and $18 \mathrm{~km}$ and can be subdivided into four characteristic regions: the Old Land, the Middle Land, the New Land, and the Deep Polders (TAvernier et al., 1970). The Old Land was brought under cultivation during the eighth and the ninth centuries and has elevations between $2.3 \mathrm{~m}$ TAW and $3.8 \mathrm{~m}$ TAW. It is located behind the first line of dikes, the alignment of which is perpendicular to the coastline protecting the inhabitants from flooding from tidal channels. In the Old Land there is a pronounced inversion of the landscape due to differential settling of clay-covered peat areas and sandy creeks, with the creeks becoming the higher areas. Farmhouses are mostly situated on sandy creek ridges. The Middle Land was reclaimed during the 11th and 12 th centuries and is situated on former tidal channels. Due to a thicker clay cover throughout this area the landscape inversion is less pronounced and human occupation is more evenly distributed than in the Old Land. The New Land was reclaimed after the 12 th century and has a limited lateral extension. These rather small areas are very flat, and the ground level is situated above $4 \mathrm{~m}$ TAW. The Deep Polders are the two lowest areas comprising lake beds that were reclaimed during the 17th century. Their extent is rather limited ( $c a .2300$ ha) with ground level lying between $1 \mathrm{~m}$ TAW and $2 \mathrm{~m}$ TAW.

The coastal dunes range in height between $5 \mathrm{~m}$ TAW and $30 \mathrm{~m}$ TAW, with the majority between $7 \mathrm{~m}$ TAW and $15 \mathrm{~m}$ TAW contributing substantially to the defence of the polders. 
At the western Belgian coastal plain (west of the IJzer estuary) the dunes are approximately $2 \mathrm{~km}$ wide. East of the IJzer estuary the dune belt is only a few hundred metres wide, except for three places (Westende, De Haan, and Knokke) where the maximum dune width is about $2 \mathrm{~km}$. The future natural development of the dune belt is inhibited by the presence of large urbanised areas and a four-lane coastal road. Nature reserves cover a large area in the dunes of the western coastal plain (738 ha). The largest reserve, De Westhoek, contains almost every representative type of dune vegetation and forms part of a cross-border reserve along with the French reserves La Dune du Perroquet and La Dune fossile de Ghyvelde. Two other important reserves on the west coast are the Houtsaegerduinen and the Ter Yde dune complex. East of the IJzer estuary nature reserves in the dunes are strongly fragmented with the exception of the D'Heye dunes of Bredene and De Haan.

The foreshore, backshore, and the dunes constitute a natural defence against the sea. The shape and position of the coastal barrier is heavily dependent on the direction and strength of the winds, tides, currents, and waves. Waves are mainly driven by westerly winds and by periodical storm surges with a southwest, west, or northwest wind direction. Tides have an amplitude of 2.6-5.4 $\mathrm{m}$ and are semidiurnal tides. The major part of the Belgian intertidal zone has a gentle slope (approximately 1\%), and the distance between low and high water springs ranges from $100 \mathrm{~m}$ to $600 \mathrm{~m}$. The sediments on the shore are almost exclusively well sorted fine to medium sands (median $0.18 \mathrm{~mm}$ ). There are peat outcrops on the foreshore from $3-5 \mathrm{~km}$ west of Oostende. The only nature reserve on the shore is situated east of the Zeebrugge harbour dike. The nature reserves of the IJzer Estuary and het Zwin include mud flats, saltmarshes, low-lying polders, dunes, and shore. The area around the harbour also consists of low-lying polder areas.

\section{Hydrogeology}

Under rising sea levels, salinisation is a major risk. The salt-freshwater interface within the groundwater of the Belgian coastal plain was first mapped by a geo-electrical survey (DE BREUK et al., 1974). A detailed distribution of fresh, brackish, and saltwater was determined throughout the western Belgian coastal plain by performing a number of resistivity borehole cross-sections (LEBBE and PEDE, 1986) (see e.g., Figure 3). In the polders, the phreatic aquifer consists mainly of pervious sediments in which a large freshwater lens occurs above saltwater. ${ }^{2}$ Intensive superficial drainage in these areas obstructs the deep infiltration of freshwater. In the Deep Polders, brackish water is found due to the mixing of infiltrating freshwater and an upward flow of saline groundwater.

In the dune areas, the phreatic aquifer is completely filled with freshwater (Figure 3) that is exploited for water supply to its maximum capacity (e.g., at Koksijde and Knokke). At De Panne there is overexploitation and the freshwater lens

\footnotetext{
2 The saltwater is connate, i.e., trapped in the sediments since deposition.
}

is threatened by saltwater flowing seaward from the polders toward the dunes. Salinisation from the sea is also a threat to the aquifer in the dunes because on the higher part of the shore saltwater infiltrates during high tides and during low tides there is seepage of saltwater on the lower part of the shore. This shallow saltwater cycle results in a saltwater lens in the upper part of the unconfined aquifer along the shore above the freshwater. This salt-freshwater inversion is typical for shores with a pervious subsoil, a rather low inclination, and fairly high tidal fluctuation and/or quite high waves (LEBBE, 1999). The water-collection areas in the dunes are not threatened by sea-level rise, as can be deduced from the general saltwater intrusion literature (e.g., BEAR, 1979; DoMENICO and SchwARTZ, 1990; FREEZE and CHERRY, 1979; TODD, 1980). However, higher sea levels do increase saltwater infiltration and may increase salinity in the water collection areas as well as promote landward seepage of saltwater into the polders behind the narrow dunes. In the narrow dunes the freshwater lens sits above saltwater, which flows very slowly landward into the low-lying polders. This salinisation process is already a problem that sea-level rise will exacerbate.

\section{COASTAL CHANGE}

This section considers coastal change and its drivers along the Belgian coast, with an emphasis on sea-level change and coastal monitoring.

\section{Sea-Level Change}

Sea level has been rising since the end of the Last Glacial Stage some 10,000 years ago. Sea level was then some 100 $\mathrm{m}$ lower than today. Between 15,000 and $7000 \mathrm{BP}$, sea level rose rapidly. Subsequently, sea-level rise continued but at a decreasing rate on the order of $0.1-0.2 \mathrm{~mm} / \mathrm{y}$ during the last 1000 years. Sea level is still adjusting to the effect of the last glaciation/deglaciation (WARRICK, 1993). DENYs and BAETEMAN (1995) and BAETEMAN and DENYs (1997) constructed a sea-level rise curve for the Belgian coast (although most of their basal peat cores used for carbon dating were derived from the western coastal plain). They found two marked regressions: (i) between 7500 and 7000 calibrated years BP and (ii) around 5500 to 5000 calibrated years BP. In an attempt to investigate sea-level rise in the very recent past (the last 2500 years), Louwye and DECLERCQ (1998) focused their attention on indicators such as height of tidal levees, height of mature salt marshes, and height of upper tidal flat deposits. Their results indicate a slow rise of spring high water levels from the 17 th century to the present day. No evidence was found for relative sea-level rise between AD 600-800 and the medieval climate optimum between $\mathrm{AD} 1000$ and 1350. The authors conclude, provisionally, that during the last 700 years the local mean spring high water could have risen a maximum of $0.55 \mathrm{~m}$, which is a considerably slower rate than that observed during the last 160 years.

DE KRAKER (1999) studied Flemish documents originating Gfrom a polder region between Gent and Antwerpen dating from the period 1488 to 1609 . These documents, which are continuous and homogeneous, contain annual dike invest- 

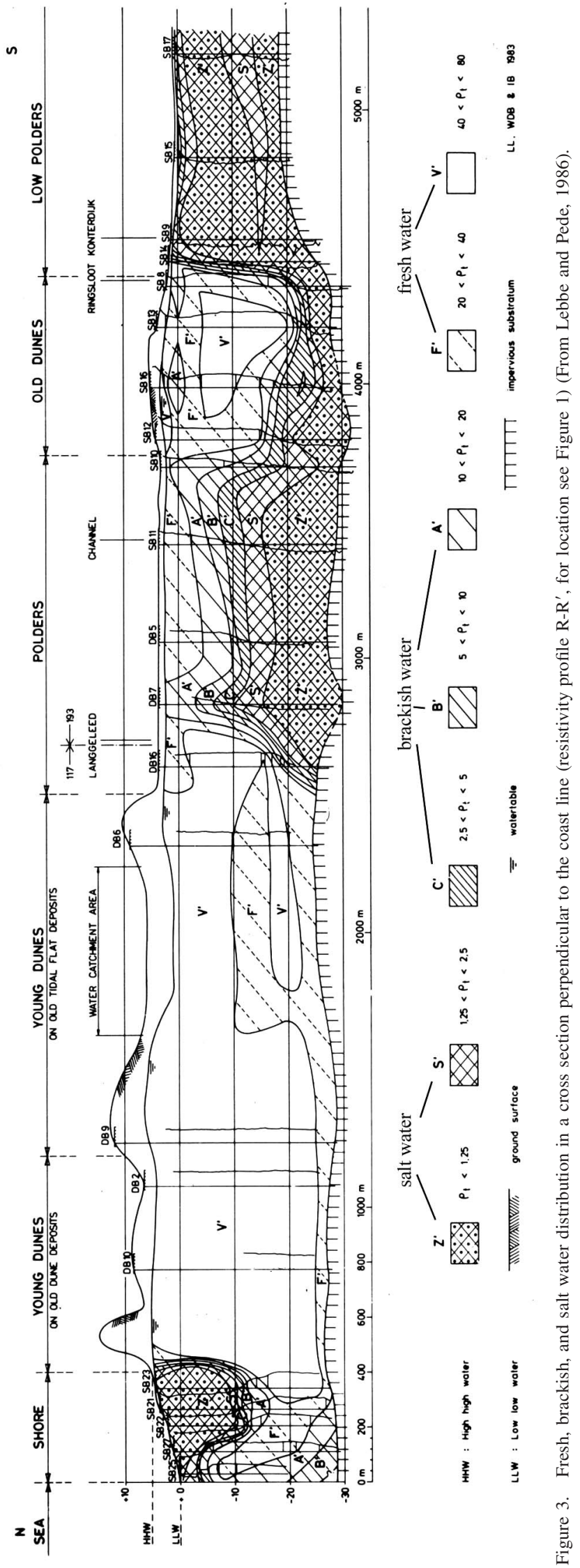
Table 1. Variation in high water level (HW), mean sea level (MS), and low water level (LW) (Van Cauwenberge, 1999).

\begin{tabular}{lccc}
\hline \hline \multicolumn{1}{c}{ Station } & $\begin{array}{c}\text { HW } \\
\text { (m/decade) }\end{array}$ & $\begin{array}{c}\text { MS } \\
\text { (m/decade) }\end{array}$ & $\begin{array}{c}\text { LW } \\
\text { (m/decade) }\end{array}$ \\
\hline Oostende (1927-1998) & 0.0217 & 0.0144 & 0.0084 \\
Zeebrugge (1964-1998) & 0.0170 & 0.0150 & 0.0086 \\
Nieuwpoort (1967-1998) & 0.0412 & 0.0277 & 0.0188 \\
\hline
\end{tabular}

ments and record nearly every storm that caused damage to the dikes. To assess the impact of storminess, eight separate storm categories were distinguished based on three principles: (i) the exact wording in the text, (ii) the circumstances in which a storm appeared, and (iii) the consequences of a storm, e.g., area flooded. Interpreting the data using this method indicates a small increase in storminess during the first quarter of the 16th century and a large increase in storminess during the second half of the 20th century. The storm surge records of Vlissingen (1848-1990) containing the date and duration of storm surges and the maximum level for each high tide of the storm surge reveal a corresponding increase in storminess beginning around the 1950s.

In Belgium three tide gauges are installed along the coastline, situated in Oostende, Zeebrugge, and Nieuwpoort. Measurements are taken and interpreted by the Coastal Hydrographic Service (part of the Waterways and Maritime Affairs Administration), and the information is then passed on to the Permanent Service for Mean Sea Level. Oostende has the longest available record, from 1835 to present. Unfortunately, the most reliable record begins in 1927, and its continuity was interrupted during World War II. For Zeebrugge and Nieuwpoort, data are available from 1964 and 1967 onward, respectively. A linear curve fitting gave the results listed in Table 1. The correlation coefficients are statistically significant and show a rising trend (Figure 4).

The higher values derived for the Nieuwpoort station are partly due to a local subsidence of the quay wall. The other results are comparable to the results found for neighbouring countries as well as the global mean sea-level change calculated for the past century (15-20 cm) (e.g., Douglas, 2001). The results support the assumption that Belgium is geologically stable and not prone to significant regional subsidence, although localised subsidence does occur e.g., Nieuwport and in the polders.

It should be noted that the high water (HW) level is increasing more than the low water (LW) level, indicating an increase in tidal amplitude (VAN CAUWENBERGE, 1999). This is supported by the data for Oostende and Vlissingen when analysed with cyclic curve fitting, which is based on a nodal tidal cycle of 18.61 years. The time series from Oostende has 3.67 nodal cycles, and the time series from Vlissingen has 5.86 nodal cycles. Cyclic curve fitting suggests an increase in $\mathrm{HW}$ at Oostende of $2 \mathrm{~mm} / \mathrm{y}$ and an increase in $\mathrm{LW}$ of $1 \mathrm{~mm} / \mathrm{y}$. In Vlissingen the increase for $\mathrm{HW}$ is $3 \mathrm{~mm} / \mathrm{y}$, but again about $1 \mathrm{~mm} / \mathrm{y}$ for LW. In contrast to The Netherlands (Vlissingen), the Belgian coast is considered geologically stable, so regional land subsidence is assumed to be negligibly small. For Nieuwpoort and Zeebrugge the time series of tide gauge observations is too short for this type of regression analysis.
Tide gauge data during the past 100 years also exist for the river Schelde in Antwerpen. This also indicates an increase in tidal amplitude as mean HW levels rise and mean LW levels decrease (Table 2). The $56-\mathrm{cm}$ rise in high water levels during a period of 90 years is obvious and has raised flood risk along the estuary. The reason for the increase of the mean HW level at Antwerpen is mainly due to human modifications in and around the estuary and partly due to relative sea-level rise. Human modifications comprise dredging, dike construction, urbanisation, rectifying the course of the estuary, etc. The lowering of the mean LW level in Antwerpen is probably due to an improved low tide flow in the Westerschelde and the lower Zeeschelde (ViaEne, 2000). The height of extreme storm floods is a basic criterion for dike construction, and an increase in storm flood heights are observed. This increase is due to a rising level of high tides, and a changing definition of "storm flood height" (i.e., $+6.5 \mathrm{~m}$ TAW before 1980 and +6.6 m TAW after 1980). However, this does not imply a significant increase in the incidence of floods, as the dikes around Antwerpen have already been, or are being, raised to protect against an extreme water frequency of 1/4000 years (ZANTING and TEN THIJ, 2001).

\section{Erosion and Accretion}

Erosion and accretion along the Belgian coast are carefully monitored. Since 1983 an annual aerial survey of the foreshore, backshore, and dunes has been carried out in spring over the entire coast with additional flights in autumn over the most threatened parts of the coast. Since 1985 more information has been gathered with a hydrographic hovercraft for the acquisition of bathymetric nearshore data, which have revealed a sequence of alternating erosional and accretional sections (DE WoLF et al., 1993). The most marked example is around De Haan where coastal defence structures do not change the course of an erosive megaprotuberance. DE MOOR (1992) defines this as

\begin{abstract}
a longer term coastal dynamics component, embracing a coastal section of a few kilometres length and characterised by a residual erosion continuing over several decades, changing in intensity and sweeping along the coastline slowly in the direction of the residual current, so that it locally presents a longer term cyclic character and is followed by an accretional phase.
\end{abstract}

This has led to a significant landward retreat of the coastline near De Haan (ca. $70 \mathrm{~m}$ at the low waterline from 1983 to 1992). Despite the application of the Longard system and beach nourishments, sand losses of almost $20 \mathrm{~m}^{3} / \mathrm{m} / \mathrm{y}$ are observed (DE WoLF et al., 1993). Most accretion along the coastline is related to defence structures, e.g., accretion at Koksijde and Nieuwpoort can be attributed to new groynes, and near Wenduine and Blankenberge to new groynes, beach scrapings, and nourishment. The construction of osier hedges along the coastline has trapped large quantities of sand since 1983 (DE WOLF et al., 1993). Without these numerous protection measures, natural evolution along the Belgian coastline would be long-term erosion and landward retreat (DE MoOR, 
Year vs. HW

$\mathrm{HW}=2.1819+.00105^{\circ}$ Year

Oostende HW 1835-1852/ $1927 \cdot 1998$ Correlation: $r=.79230$

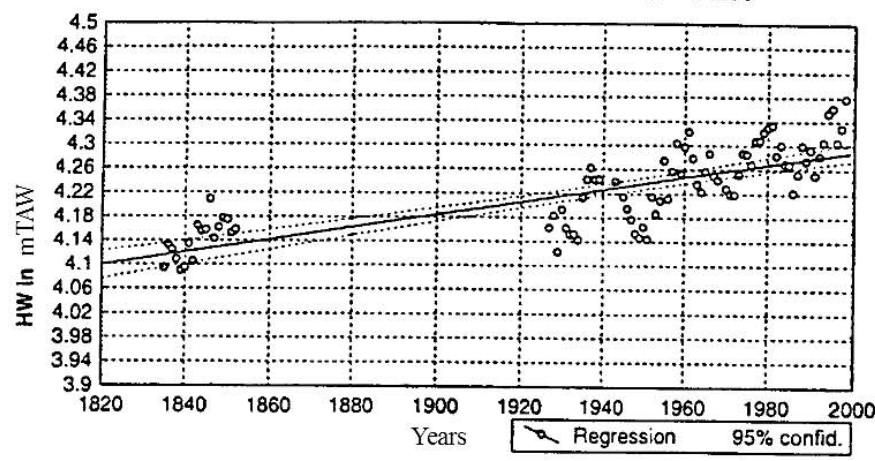

Yearvs. MSL

$M S L=.25183+.00102 \cdot$ Year

Oostende MSL 1835-1852 /1927-1998 Correlation: $r=.90585$

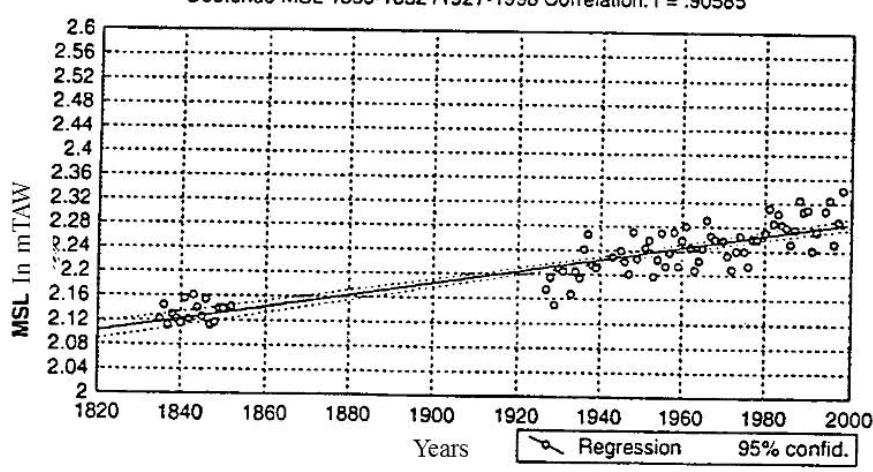

Year vs. LW

$L W=-1.604+.001011^{*}$ Year

Oostende LW 1835-1852/1927-1998 Correlation: $r=.79116$

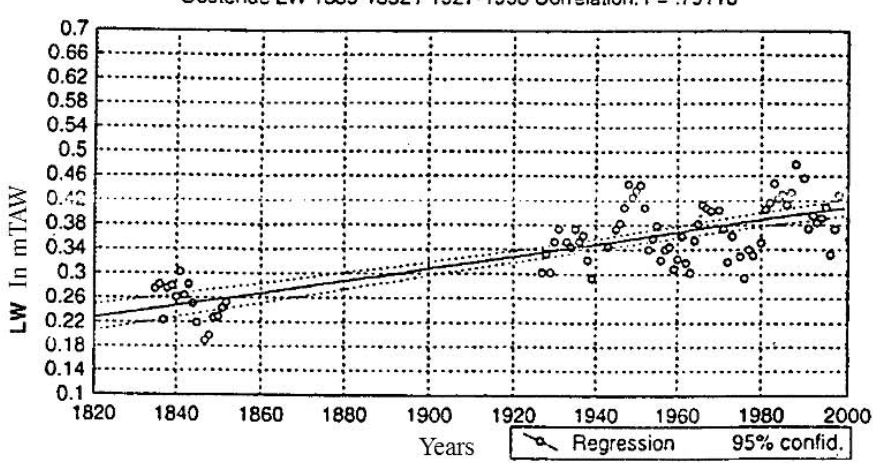

Year vs. HW

$\mathrm{HW}=\cdot .0106+.00217{ }^{\circ}$ Year

Oostende HW 1927-1998 Correlation: $r=.76353$

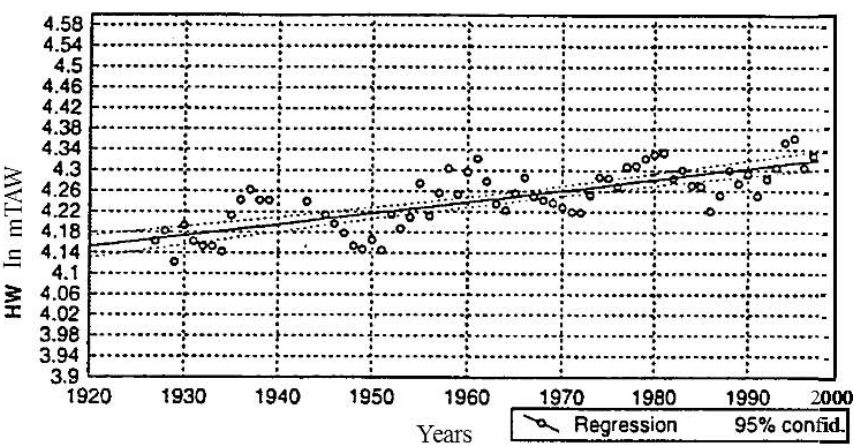

Year vs. MSL

MSL $=-.5811+.00144^{\bullet}$ Year

Oostende MSL 1927.1998 Correlation: $r=.76372$

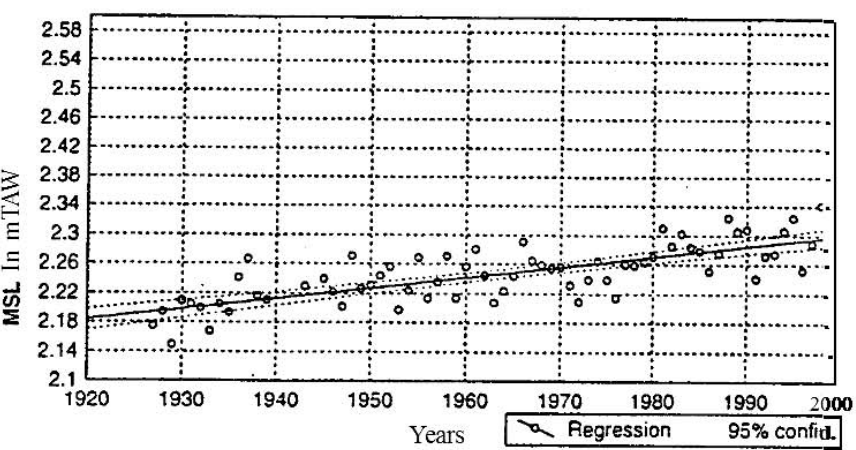

Year vs. LW

$L W=-1.278+.00084 \%$ Year

Oostende LW 1927-1998 Correlation: $r=.38247$

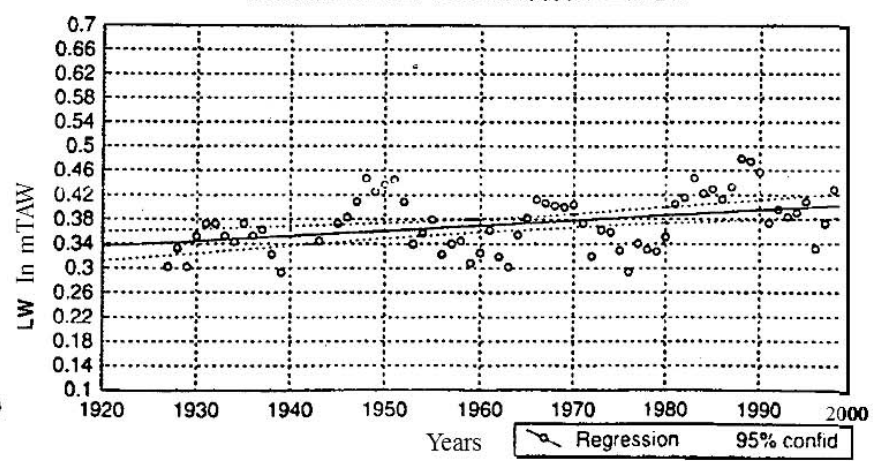

Figure 4. Evolution of high water level (HW), mean sea level (MSL), and low water level (LW) in Oostende for the periods 1835-2000 and $1930-2000$ (From van Cauwenberge, 1999).

1992; DE WOLF et al., 1993), which can probably be attributed to a long-term sediment deficit.

\section{Saltwater Intrusion}

At present, monitoring of saltwater intrusion is not carried out systematically. Only sporadic geo-electrical surveys and water analyses are made, but usually not with the intention of monitoring saltwater encroachment.

\section{NATURAL AND ARTIFICIAL COASTAL DEFENCE}

The natural defence of the Belgian coast consists of a sandy foreshore, backshore, and dune belt. This natural protection 
Table 2. Decadal trends of mean high water (MHW) and mean low water levels (MLW) along with the tidal amplitude (MTA) for a period of 100 years near Antwerpen (Viaenen, 2000).

\begin{tabular}{cccc}
\hline \hline Decade & MHW (m TAW) & MLW (m TAW) & MTA (m) \\
\hline $1891-1900$ & 4.68 & 0.29 & 4.39 \\
$1901-1910$ & 4.72 & 0.23 & 4.49 \\
$1911-1920$ & 4.83 & 0.24 & 4.59 \\
$1921-1930$ & 4.85 & 0.20 & 4.65 \\
$1931-1940$ & 4.90 & 0.18 & 4.72 \\
$1941-1950$ & 4.90 & 0.17 & 4.73 \\
$1951-1960$ & 4.96 & 0.15 & 4.81 \\
$1961-1970$ & 5.07 & 0.17 & 4.90 \\
$1971-1980$ & 5.15 & 0.01 & 5.14 \\
$1981-1990$ & 5.24 & 0.05 & 5.19 \\
\hline
\end{tabular}

extends along $40 \%$ of the coastline with additional artificial defence structures elsewhere to ensure the preservation of the present shape and situation of the coastline. These artificial defences are categorised as hard or soft (MVG, 1993). Soft protection measures that have been applied to the Belgian coast include beach nourishment, near-shore nourishment, temporary wind screens, sand berms on the back shore, beach scrapings, and planting of osier hedges or marram grass (MVG, 1993). The Longard tube system was built at Lombardsijde and De Haan, accompanied by beach nourishment of $40 \times 10^{3} \mathrm{~m}^{3}$ over 1.25 -km length in 1981 and $12.5 \times$ $10^{6} \mathrm{~m}^{3}$ over 4-km length in the period from 1978 to 1980 . Other important beach nourishment schemes occurred at Blankenberge $\left(30 \times 10^{3} \mathrm{~m}^{3}\right.$ in 1988) and at Knokke $(>8 \times$ $10^{6} \mathrm{~m}^{3}$ in 1977-1979 and $1 \times 10^{6} \mathrm{~m}^{3}$ in 1986). At Knokke, an experiment with underwater screens to stabilise the beach and prevent cross-shore erosion was performed.

Sea dikes and dikes presently protect coastal cities such as Oostende, Zeebrugge, De Haan, and De Panne, etc. against storm surges and high waves. These dikes are usually combined with groynes and shorter beach groynes. Currently, no clear idea or inventory exists about the actual defence strength of most dikes and sea dikes in Belgium (MVG, 1993), although maintenance and investment costs for coastal defence are about $€ 25$ million per year (P. DE WOLF, personal communication).

Antwerpen and other cities/villages along the Schelde estuary are protected against flooding and inundation by dikes. These dikes will shortly be raised to attain the presently required standard level protection against flooding for a storm frequency of $1 / 4000$ years. Another potential protection measure is the creation of controlled flooding areas, which is now under discussion (ZANTING and TEN THIJ, 2001). These are areas that will accommodate the extra water generated during dangerously high water levels to reduce the threat to urban areas and other valuable land. These measures are part of the SIGMA-plan (plan for the development of steps against inundations of the river Schelde).

\section{VULNERABILITY OF COASTAL AREAS}

Some of the possible implications of sea-level rise for Belgium are now considered, with a strong emphasis on the implications for groundwater, drainage, and rising water tables.
Flooding and erosion are important concerns. Despite the natural and artificial defence structures, the coastal plain will always remain vulnerable to changes in sea level or storm frequency. One example is the city of Oostende. At present, only an old sea dike protects it against flooding. The beach at Oostende is narrow and offers limited protection. The dike was constructed for a storm frequency of 250 years. For future upgrade, a storm frequency of 4000 years will be used in the design (DE RoEcK, 1999). Another part of the flood defence plan is to widen the shore through beach nourishment ( $\mathrm{P}$. DE WoLF, personal communication). Concrete sea walls counteract the natural exchange of sediments between foredunes, beach, and offshore (BAETEMAN et al., 1992). Consequently, the sand necessary to maintain the beach profiles under sea-level rise cannot be delivered by the erosion of the foredune. This will result in accelerated beach erosion, and the undermining of the seawall is not inconceivable if there is not ongoing nourishment.

The polder area is protected by dikes and is surrounded and intersected by canals that drain most of the infiltrating freshwater almost immediately. Sea-level rise would increase the risk of saltwater seepage into the polder area, especially into the polder areas immediately landward of the narrow dune belts. On the seaward side of the dunes the landward infiltration of saltwater will increase because of rising high water levels. This would result in increased saltwater seepage into polder areas, an increased amount of drainage water, and an increase of salt content in the drained water. The increased infiltration of saltwater on the shore in front of the wide dune belt will result in a larger saltwater lens on the shore, which occurs above the reduced flow of freshwater from the dunes toward the sea (Figure 3). Sea-level rise and any increase of tidal amplitude will result in rising water tables in the dune area, possibly leading to flooding of old cellars, underground car parks, and other underground services.

Sea-level rise and any increase in tidal amplitude will reduce the water extraction capacity in the wide dune belt. At a constant discharge rate and after a certain rise of the high high water level, saltwater will start to flow from the shore to the extraction wells. Possible measures against this saltwater intrusion are: (i) reducing the extraction rate of the wells close to the seaside, eventually combined with increasing the discharge rate of the well close to the polder area and (ii) artificial recharging of the dune area close to the sea, among others. For an optimal design of such adaptation measures, detailed hydrogeological studies will be necessary. Preliminary response measures have already been considered (LEBBE et al., 1995). Artificial recharge could be realised with surface water and/or effluent from a wastewater treatment plant, including cleansing with ultrafiltration or inverse osmosis (VAN HouTTE et al., 1998).

At present, a large part of the surface water of the coastal plain and its surrounding areas flows by gravity to the sea through locks that are only open at low tides. Because of this limitation, clay-covered peat areas are regularly flooded during wetter periods (BAETEMAN et al., 1992). This is particularly true for those areas on the right bank of the river IJzer, which has lower dikes than the left bank. Additionally, drain- 
age water of the left bank can also be pumped continuously into the sea behind the Nieuwpoort Locks (total discharge rate capacity of $28 \mathrm{~m}^{3} / \mathrm{s}$ ) when the gravitational flow is too small. Isolated small, low areas in the polders are also equipped with pumps, which lift the water into larger canals with gravitational flow to the sea (e.g., the reclaimed lakes and the clay-covered peat areas situated near the landward boundary of the polders). Sea-level rise, tidal amplitude increases, and rain intensity increases will all have their influence on the proper management of the drainage system even if an enlargement of wetland areas is taken into account. In these areas a rise of the drainage level is considered (e.g., the Uitkerkse polder, $127 \mathrm{ha}$ ). Polders requiring improved drainage in rain intensive periods should be managed to avoid increased subsidence.

The Schelde estuary is also an important natural site, including precious intertidal flats and associated ecosystems. It is not yet clear if anthropogenic changes in recent years have caused a threat to these areas and communities. Current sediment losses out of the estuary could, along with sea-level rise, cause drowning of some nature reserve areas, such as the intertidal flats. Further research on this issue is necessary (ZANTING and TEN THIJ, 2001).

\section{CONCLUSION AND FUTURE RESEARCH ISSUES}

Although the hinterland is naturally protected by foreshore, backshore, and dunes, this natural protection exists for only $40 \%$ of the Belgian North Sea coast. The remainder is protected by dikes, sea dikes, groynes, and other (soft) protection measures in an attempt to maintain the present width of shore and dunes. About $€ 25$ million is spent each year on maintenance of, and investment in, coastal defences. Adaptation to sea-level rise is necessary to protect the densely populated coastal area, where economic activity is important and dependent on the present shape of the coastline and on the drainage level of the coastal plain. Sea-level rise will make more artificial drainage necessary and will necessitate extensive application of protective measures to maintain the coastline, including the Schelde estuary.

The main morphological features of the coastal plain are artificial or human influenced ( $c f$. VAN KONINGSVELD et al., 2008). Low-lying polders are completely artificial and intersected by canals that conduct the water from the higher surrounding areas by gravitational flow through the locks to the sea. Sea-level rise and any increase of tidal amplitude will reduce this drainage capacity while, at the same time, the need for drainage capacity is expected to increase as rain intensity increases. Important freshwater resources in the coastal dunes are also threatened. These qualitative deductions assume that the drainage levels in the polder areas remain unaltered. Thorough hydrogeological studies are necessary to maintain fresh groundwater reserves in the Belgian coastal plain.

Sea-level rise monitoring shows that high water level has risen about an average of $20 \mathrm{~mm} /$ decade and mean sea level an average of $15 \mathrm{~mm} /$ decade over the 20th century. Coastal management is focused on preserving the present shoreline. New dike design criteria in Belgium are comparable to Dutch criteria, which are based on an increasing storm risk and a future sea-level rise of $6 \mathrm{~mm} / \mathrm{y}$ (DE ROECK, 1999). Increased drainage in the polders will be necessary to remove the extra saltwater seepage and increased rain intensity. Some studies on the effects of sea-level rise on the Belgian coast have been carried out (SCHOETERS and VANHAECKE, 1999; VIAENE, 2000), but they are based on results from other European studies, which have then been extrapolated to the Belgian situation.

This investigation has highlighted the need for future research to focus on the quantitative interpretation of the available data, such as numerical modelling of sediment transport and groundwater flow, in order to understand the effect of sea-level rise on beach erosion, flood risk, fresh and saltwater distribution, etc. The collection of additional data on freshsaltwater distribution, sediment distribution, and the effect of dredging along the shoreline would also be of benefit. Future research should also consider the Intergovernmental Panel on Climate Change scenarios of sea-level rise and climate change. This basic data could then be used for planning and reevaluation of coastal management decisions. Beside the elaboration of physical models, data acquisition, and calibrations, a thorough socio-economic study should be made to assess the vulnerability of the Belgian coast. Lastly, the vulnerability of the Western Schelde Estuary should be further assessed in close collaboration with The Netherlands.

\section{ACKNOWLEDGMENTS}

The authors would like to thank three anonymous reviewers. R. Nicholls and A. de la Vega-Leinert are acknowledged for their editorial comments. Their suggestions and comments enhanced the quality of the paper.

\section{LITERATURE CITED}

Allaert, G., 1996. De Belgische kust: tekenen van een recente revival? Internal note (In Dutch). Department of Areal Survey, Ghent University, Belgium.

Baeteman, C.; De Lannoy, W.; Paepe, R., and van CauwenberGE, C., 1992. Vulnerability of the Belgian coastal lowlands to future sea-level rise. In: ToOley, M.J., and Jelgersma, S. (eds.), Impacts of Sea-level Rise on European Coastal Lowlands. The Institute of British Geographers Special Publications Series 27. Oxford, UK: Blackwell, pp. 56-71.

Baeteman, C. and Denys, L., 1997. Holocene shoreline and sealevel data from the Belgian coast. Paleoclimate Research, 21, 4974.

BEAR, J., 1979. Hydraulics of Groundwater. New York: McGraw-Hill. De Breuk, W.; De Moor, G.; Marechal, R., and Tavernier, R., 1974. Depth of the salt-freshwater interface in the phreatic aquifer in the Belgian coastal plain (1963-1973). Proceedings of the 4th Saltwater Intrusion Meeting (Ghent, Belgium). Appendix (map, scale 1/100.000).

DE KRAKER, A.M.J., 1999. A method to assess the impact of high tides, storms and storm surges as vital elements in climatic history the case of stormy weather and dikes in the northern part of Flanders, 1488 to 1609 . In: PFISTER, C., BRADZIL, R., and GLAsER, R. (eds.), Climatic Variability in Sixteenth Century Europe and Its Social Dimension (reprinted from Climatic Change, 43,[1]). Dordrecht, The Netherlands: Kluwer Academic Publishers, pp. 287302.

DE Moor, G., 1992. A quantitative evaluation of erosive and accretional sections along the Belgian coast in the period 1978-1990. 
Tijdschrift van de Belgische Vereniging voor Aardrijkskundige Studies (BEVAS), 2, 413-424.

DE RoEck, J., 1999. Advies betreffende de zeedijk te Oostende tussen het casino en het klein strand. Internal note (In Dutch). Waterways and Maritime Affairs Administration, Belgium.

De Wolf, P.; Fransnaer, D.; van Sieleghem, J., and Houthuys, R., 1993. Morphological trends of the Belgian coast shown by 10 years of remote-sensing based surveying. In: Proceedings of the 8th Symposium on Coastal and Ocean Management (19-23 July; New Orleans, Louisiana), pp. 245-257.

Denys, L. and BAEteman, C., 1995. Holocene evolution of relative sea level and local mean high water spring tides in Belgium-a first assessment. Marine Geology, 124, 1-19.

Denys, L.; Lebbe, L.; Sliggers, L.C.; Spaink, G.; van, S.M., and VerbrugGen, C., 1983. Litho- and biostratigraphical study of quaternary deep marine deposits of the western Belgium coastal plain. Bulletin van de Belgische Vereniging voor Geologie, T 92(2), $125-154$.

Domenico, P.A. and Schwartz, F.W., 1990. Physical and Chemical Hydrogeology. New York: John Wiley and Sons.

Douglas, B.C., 2001. Sea level change in the era of the recording tide gauge. In: Douglas, B.C., Kearney, M.S., and LeatherMAN, S.P. (eds.), Sea Level Rise, History and Consequences. New York: Academic Press, pp. 37-64.

Freeze, R.A. and Cherry, J.A., 1979. Groundwater. Englewood Cliffs, New Jersey: Prentice-Hall.

Lebbe, L. and Pede, K., 1986. Salt-freshwater flow underneath the old dunes and low polders influenced by pumpage and drainage in the western Belgian coastal plain. In: Proceedings of the 9th Saltwater Intrusion Meeting. Delft, the Netherlands, pp. 199-220.

Lebbe, L.; TARHouni, J.; van Houtte, E., and De Breuck, W., 1995. Results of an artificial recharge test and a double pumping test as preliminary studies for optimising water supply in the western Belgian coastal plain. Hydrogeology Journal, 5(3), 44-55.

LebBe, L., 1999. Parameter identification in fresh-saltwater flow based on borehole resistivities and freshwater head data. Advances in Water Resources, 22(8), 791-806.

Louwye, S. and DeclercQ, E., 1998. Relative water level change in the intracoastal zone of Belgium and Northern France over the last 2500 years. Boreas, 27, 162-177.

Mostaert, F., 1985. Een vergelijkende studie van de sedimentologie en detailstratigrafie van Eemiaan en Holocene getijdesedimenten in het oostelijk deel van de kustvlakte. Ghent, The Netherlands: Ghent University, Ph.D. thesis (In Dutch).

Mostaert, F., 1986. Kreekruggen en komgronden in het Bruse Oudland. Kritische analyse van de verschillende morfogenetische in- terpretaties. Critical analysis of different morphogenetic interpretations. Werkstukken, XXV (In Dutch). Nationaal centrum voor geomorfologisch onderzoek (NCGO).

MVG (Ministerie van de Vlaamse Gemeenschap, the Ministry of the Flemish Community), 1993. Kust 2002. Deel 1: De zeewerende functie van de kust. Stand van zaken. Preparational report for Department of Natural Environment and Infrastructure, Waterways and Maritime Affairs Administration, Harbour council (In Dutch). Ministry of the Flemish Community.

Schoeters, K. and Vanhaecke, P., 1999. Kader voor rapportering van "Climate Change" effecten in België: uitwerking en toepassing. Final report on the effects of Climate Change in Belgium: development and application (In Dutch). Ecolas, N.V. for Federal Service for Scientific, Technological and Cultural Affairs, 121p.

Tavernier, R.; Ameryckx, J.; Snacken, F., and Farasyn, D., 1970. Kust, Duinen en Polders. In: Atlas van Belgie, Plaat 17, Begeleidende tekst. Brussels, Belgium: Militair Geografisch Instituut, pp. 32.

ToDD, D.K., 1980. Groundwater Hydrology. 2nd edition. New York: John Wiley and Sons.

van Caunenberge, C., 1999. Relative Sea-Level Rise Along the Belgian Coast: Analyses and Conclusions With Respect to the High Water, the Mean Sea and the Low Water Levels. Report 46. Hydrographical Service (Oostende), Water-ways and Maritime Administration.

van Houtte, E.; Verbouwhede, J.; Vanlerberghe, F.; DemunTER, S., and CABOOTER, J., 1998. Treating different types of raw water with micro- and ultrafiltration for further desalination using reverse osmosis. Desalination, 117, 49-60.

Van Koningsveld, M.; Mulder, J.P.M.; Stive, M.J.F.; VanDerValk, L., and VanDerWeck, A.W., 2008. Living with sealevel rise and climate change: a case study of the Netherlands. Journal of Coastal Research, 24, 367-379.

ViAENE, P., 2000. Effecten van een mogelijke klimaatverandering op het zeespiegelniveau, de rivierafvoer en de frequentie van hoogwaters en stormen. Literature study (In Dutch). Ministry of the Flemish Community, Hydraulic Laboratory and Hydrological Research Division.

WARRICK, R.A., 1993. Climate and sea level change: a synthesis. In: Warrick, R.A., Barrow, E.M., and Wigley, T.M.L. (eds.), Climate and Sea-level Change, Observations, Projections and Implications. Cambridge, UK: Cambridge University Press, pp. 424.

Zanting, H.A. and Ten ThiJ, F., 2001. Lange termijn visie Schelde estuarium. Rapport Technische Schelde commissie, RA/00-45 (In Dutch). Delft, The Netherlands: RIKZ, WBL and Delft Hydraulics.

\section{$\square$ SAMENVATTING $\square$}

Zelfs al is de kustvlakte en het estuarium van de Schelde van groot economisch belang voor België en leven er ca. 0.8 miljoen mensen (op een totale bevolking van 10 miljoen), tot nu toe bestaat slechts kwalitatieve beschrijvingen over de effecten van een zeespiegelstijging op de kustvlakte. Er zijn geen kwantitatieve modellen ontwikkeld die steunen op werkelijke veldwaarnemingen. Hier worden de fysische eigenschappen van het kustgebied beschreven samen met een kwalitatieve interpretatie van zijn kwetsbaarheid. De laag-gelegen poldergebieden, die kustmatig aangelegd werden, zullen het meest beïnvloed worden door een zeespiegelstijging. Eén van de belangrijkste problemen in dit gebied is de waterevacuatie tijdens regenrijke periodes. Verschillende delen van de polders worden op verschillende wijzen droog gehouden. Hun verschillende kwetsbaarheid voor zeespiegelstijging en toename van regenidensiteit wordt ingeschat. Het verband tussen de drainageniveau's en verziltingsgevaar wordt eveneens beschreven. Ook de zoetwaterlenzen, ontwikkeld onder de duinen en geëxploiteerd voor drinkwater, worden door een zeespiegelstijging bedreigd. De kustverdedigingsstructuren en hun efficiëntie worden besproken. De effecten van een zeespiegelstijging voor de haven van Antwerpen en voor het Schelde estuarium zijn ver van duidelijk. De resultaten van het opvolgen van de zeespiegelstijging tijdens de 20ste eeuw, van het waarnemen van de winden en golven en de evolutie van erosie en accretie worden eveneens beschreven. Toekomstig onderzoek zou zich vooral moeten richten op de quantitatieve interpretatie van gegevens om zeespiegelstijgingseffecten in te schatten op stranderosie, overstromingsrisico's en zoet-zout-grondwaterdistributies Naast deze fysische modellen zou een grondige socio-economische studie moeten gemaakt worden, resulterend in een inschatting van de kwestbaarheid van het Belgische kustgebied en van het Scheldegebied. 